[0000-0002-3871-4063] 3. О. Знак, д.m.н., професор, e-mail: znak_zo@ukr.net

А. С. Грабаровська, аспірантка, e-mail: 1584466@ukr.net

O. I. Зінь, M.H.C., e-mail: zin.olha@gmail.com

А. В. Дяденчук, студент

Національний університет «Львівська політехніка» вул. С. Бандери, 12, м. Львів, 79013, Україна

\title{
МОДИФІКУВАННЯ ТЕРМІЧНО АКТИВОВАНОГО ПРИРОДНОГО КЛИНОПТИЛОЛІТУ ЙОНАМИ АРГЕНТУМУ
}

Проаналізовано області використання природного иеоліту - клиноптилоліту - як сорбенту для очищення природних і стічних вод. Зазначено перспективність модифікування цеоліту йонами Аргентуму, які надають йому антибактеріальних властивостей. Подано опис лабораторної установки та методики проведення досліджень з модифікування иеоліту. Наведено результати дегідратування природного клиноптилоліту за температур $100 \ldots 400{ }^{\circ} \mathrm{C}$ та під дією електромагнітних випромінювань надвисокочастотного діапазону. Визначено швидкість процесу дегідратаиії клиноптилоліту за різних температур. Наведено результати модифікування термічно активованого клиноптилоліту йонами Аргентуму в умовах перемімування в турбулентному режимі. Встановлено значення сорбиійної ємності клиноптилоліту щодо йонів Аргентуму та розраховано швидкості йонного обміну залежно від умов дегідратаиії цеоліту. Проаналізовано особливості заміщення обмінних катіонів клиноптилоліту йонами Аргентуму.

Ключові слова: природні сорбенти, очищення води, клиноптилоліт, модифікування, йони Аргентуму, сорбиійна ємність.

Вступ (постановка проблеми). Природні сорбенти завдяки доволі високій сорбційній ємності, низькій вартості, наявності величезного ресурсного потенціалу дедалі ширше використовують у процесах підготовки природних і очищення стічних вод. Зокрема, це стосується такого природного мінералу, як клиноптилоліт - один із різновидів цеолітів. Окрім високої сорбційної ємності, зумовленої наявністю розвиненої системи макро-, мезо- та мікропор, клиноптилоліту притаманна йонообмінна здатність, оскільки в його структурі містяться так звані обмінні йони, зокрема, кальцію, магнію, натрію, калію. Тому завдяки йонообмінній здатності клиноптилоліт часто використовують для очищення різних вод від шкідливих домішок. Так, застосування дисперсного природного цеоліту $(0,315 \ldots 0,63$ мм) забезпечило ступінь очищення води від йонів амонію не менше $95 \%$ [1]. Показано, що висока йонообмінна здатність щодо йонів амонію притаманна клиноптилоліту болгарського родовища [2]. Дослідження кінетики та рівноваги сорбції амонійних йонів на цеоліті китайського родовища (C) 3. О. Знак, А. С. Грабаровська, О.І. Зінь, А.В. Дяденчук, 2019 DOI: $10.24025 / 2306-4412.4 .2019 .183209$

підтвердило доцільність його застосування в процесах очищення вод від $\mathrm{NH}^{+}$[3]. Природний клиноптилоліт словацького родовища володіє високою ємністю щодо йонів кольорових металів, зокрема Купруму [4]. Показано, що високий ступінь очищення вод клиноптилолітом досягається за наявності йонів Цинку, Купруму та Плюмбуму [5]. Для вилучення йонів кольорових металів запропоновано використовувати натуральні та модифіковані цеоліти [6]. Для вилучення йонів важких металів з промислових вод доцільно застосовувати синтетичні та природні цеоліти [7]. Внаслідок вилучення йонів Феруму можна отримати цеоліт, який надалі можна використовувати для очищення води від йонів Флюору [8]. Встановлено, що модифіковані солями Мангану та Феруму(II) цеоліти забезпечують високу поглинальну здатність цеолітів щодо йонів Феруму(III) [9]. Активовані природні цеоліти дають змогу вилучати 3 вод сполуки Флюору [10].

У типових процесах підготовки води для господарсько-питних потреб важливою стадією є знезараження води, яке здебільшого 
здійснюють хлоруванням. У разі використання природних поверхневих вод, що містять різноманітні органічні сполуки, хлорування може призвести до утворення хлорпохідних цих органічних сполук, більшості з яких притаманна канцерогенна дія. Тому в розвинених країнах альтернативою хлорування є використання озонування, ультрафіолетове знезаражування, а також використання нанокомпозитів на основі срібла, яке володіє вираженою окисною здатністю. Наприклад, запропоновано модифікувати природні цеоліти, в тому чисті й клиноптилоліт, йонами Аргентуму, які надають мінералу ще й дезифінкувальних властивостей [11]. Нанокомпозитні матеріали на основі модифікованого сріблом цеоліту застосовують у фільтрах для води [12]. Попереднє кислотне модифікування цеоліту дає змогу здійснити ефективніше його модифікування сполуками Аргентуму [12]. Одночасно це дає змогу розширити сфери використання клиноптилоліту, модифікованого йонами Аргентуму, зокрема в медицині, харчовій промисловості, сільському господарстві та інших галузях економіки. Загалом, фізичне (термічне) та хімічне модифікування цеолітів, як природних, так і синтетичних, стало традиційним способом покращення їх йонообмінних та сорбційних властивостей. Однак наявні в джерелах інформації відомості щодо умов модифікування та їх вплив на сорбційну ємність клиноптилоліту щодо йонів Аргентуму є вельми обмеженими, що й зумовило мету цих досліджень.

Метою роботи було дослідження впливу умов дегідратації природного клиноптилоліту на кінетику його модифікування йонами Аргентуму та величину сорбційної ємності цеоліту за йонами $\mathrm{Ag}^{+}$.

Експериментальна частина. У дослідженнях використовували природний клиноптилоліт Сокирницького родовища (ТУ У 20.5-43073742-002:2019). Для очищення цеоліту від домішок, передусім глини, що зазвичай входить до складу цеолітової породи, товарну фракцію клиноптилоліту 2-3 мм впродовж 10 хв. подрібнювали до фракції $<2,0$ мм у кульовому млині (об'єм барабана -

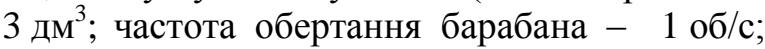
масове співвідношення клиноптилоліт : молольні тіла $=1: 1$; ступінь заповнення барабана - $50 \pm 5 \%$ ). Після подрібнення фракцію $<0,25$ мм, в якій вміст глинистих частинок був найбільшим, відсіювали. Фракцію клинопти-

(C) 3. О. Знак, А. С. Грабаровська, О.І. Зінь, А.В. Дяденчук, 2019 DOI: $10.24025 / 2306-4412.4 .2019 .183209$ лоліту $>0,25$ мм надалі знову розмелювали на кульовому млині.

Оскільки процес модифікування є типовим гетерогенним, то для зменшення впливу фракційного складу на результати усі дослідження проводили 3 використанням вузької фракції клиноптилоліту - 0,056...0,063 мм.

Визначення температурного діапазону термічного оброблення природного клиноптилоліту $з$ метою його дегідратації перед модифікуванням йонами $\mathbf{A g}^{+}$проводили методом диференційно-термічного аналізу (ДТА) 3 використанням дериватографа Q-1500 D системи "Paulik-Paulik-Erdey".

За результатами ДТА термооброблення клиноптилоліту надалі проводили в діапазоні температур $373 \ldots 773$ К. Окрім того, цеоліт піддавали обробленню надвисокочастотним (НВЧ) електромагнітним випромінюванням 3 частотою $2,45 \pm 0,05$ ГГц потужністю $400 \pm 25$ Вт (за нижчої потужності ефективність поглинання НВЧ-випромінювань клиноптилолітом $€$ незначною [14]).

Ступінь дегідратації цеоліту визначали гравіметрично за допомогою аналітичної ваги Axis A-500. Значення цього показника впродовж термооброблення (та оброблення НВЧвипромінюванням) визначали за формулою

$$
x=\frac{m_{Z e, 0}-m_{Z e, i}}{m_{\text {gid }}} 100,
$$

де $m_{Z e, 0}-$ початкова маса зразка цеоліту, г;

$m_{Z e, i}-$ поточна маса зразка цеоліту, г;

$m_{\text {gid }}-$ маса води у зразку цеоліту, яку визначали при нагріванні клиноптилоліту до температури $450{ }^{\circ} \mathrm{C}$, г.

Дослідження модифікування природного клиноптилоліту йонами Аргентуму проводили на установці, зображеній на рисунку 1. До ii складу входили: ультратермостат UT-8 (1); термостатна ванна (2), яка розташована на магнітній мішалці (8); хімічна склянка (4), в якій проводили модифікування клиноптилоліту і яка розташована в термостатній ванні (2); Ag-селективний електрод (ESS-01) (5), який разом 3 хлорид-срібним електродом (EVL-1M), комутованим 3 мілівольтметром Ф-30 (3), слугував для визначення концентрації йонів Аргентуму в розчині; електролітичний мостик (6), заповнений агар-агаром; проміжна ємність (7), заповнена електролітом $\left(0,1 \mathrm{~N}\right.$ розчин $\left.\mathrm{KNO}_{3}\right)$. 


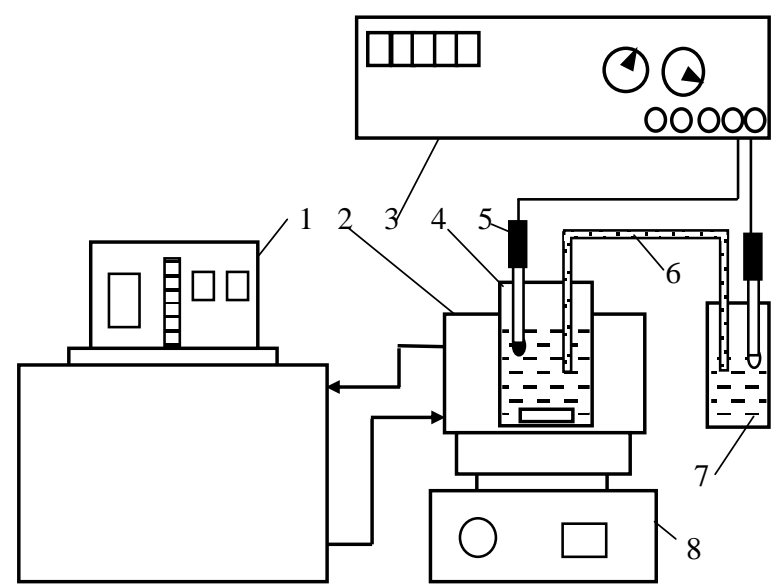

1 - ультратермостат; 2 - термостатна ванна; 3 - мілівольтметр; 4 - хімічна склянка;

5 - Ag-селективний електрод; 6 - мостик;

7 - хлоридсрібний електрод порівняння; 8 - магнітна мішалка

Рисунок 1 - Схема лабораторної установки

Модифікування клиноптилоліту проводили в розчині $0,1 \mathrm{~N} \mathrm{AgNO}_{3}$ за постійного перемішування суспензії цеоліту в турбулентному режимі в діапазоні температур $20 \ldots 60$ С. Дослідження проводили за п'ятиразового надлишку йонів $\mathrm{Ag}^{+}$щодо обмінних йонів цеоліту (в еквівалентному вираженні). Надлишок йонів $\mathrm{Ag}^{+}$був необхідний для досягнення рівноваги процесу обміну катіонів, що входять до складу клиноптилоліту, на йони Аргентуму з розчину. Періодично в розчині потенціометрично визначали залишкову концентрацію йонів $\mathrm{Ag}^{+}$. Тривалість процесу йонного обміну не перевищувала 30 хв., що попередньо встановлено експериментально.

Ag-селективний електрод перед кожним дослідженням калібрували в розчинах $\mathrm{AgNO}_{3}$ $\left(1 \cdot 10^{-4} \ldots 1 \cdot 10^{-1}\right.$ екв/дм $\left.{ }^{3}\right)$.

Після досягнення сталого значення потенціалу Ag-селективного електрода, тобто після припинення йонного обміну в системі розчин-цеоліт, дисперсний клиноптилоліт відфільтровували на мембранному фільтрі, цеоліт на фільтрі промивали дистильованою водою об'ємом $250 \mathrm{~cm}^{3}$. У промивній воді визначали вміст йонів Аргентуму, який надалі (разом із загальним об'ємом промивних вод) враховували під час визначення сорбційної ємності певного зразка клиноптилоліту.

Після закінчення процесу модифікування методом зворотного йонного обміну визначали вміст йонів Аргентуму в клиноптило-

(C) 3. О. Знак, А. С. Грабаровська, О.І. Зінь, А.В. Дяденчук, 2019 DOI: $10.24025 / 2306-4412.4 .2019 .183209$ літі. Для цього модифікований цеоліт промивали дистильованою водою і обробляли $1 \mathrm{M}$ розчином $\mathrm{HNO}_{3}$, взятим з 10-разовим надлишком щодо вмісту йонів $\mathrm{Ag}^{+}$в цеоліті, попередньо визначеним за зміною їх концентрації під час модифікування. Вміст йонів $\mathrm{Ag}^{+}$в отриманому розчині визначали потенціометрично.

Відносна похибка визначення вмісту йонів $\mathrm{Ag}^{+}$у клиноптилоліті (під час модифікування та внаслідок зворотного йонного обміну) не перевищувала $6 \%$.

Ступінь заміщення обмінних катіонів, що містяться у клиноптилоліті, на йони Аргентуму визначали за формулою

$$
x_{A g}=\frac{E_{A g}}{E_{0}} 100,
$$

де $E_{0}$ - інтегральна іонообмінна ємність вихідного клиноптилоліту, мекв/г;

$E_{A g}-$ досягнута іонообмінна ємність клиноптилоліту за йонами $\mathrm{Ag}^{+}$, мекв/г.

Результати та їх обговорення. Методом термогравіметричного аналізу встановлено, що дегідратація природного клиноптилоліту головно відбувається в два етапи. На першому - до температури близько $115^{\circ} \mathrm{C}$ відбувається видалення фізично сорбованої води, що відображається у вигляді глибокого чітко вираженого ендоефекту (рисунок 2, лінія DTA), який супроводжується відповідною втратою маси (рисунок 2, лінія DTG).

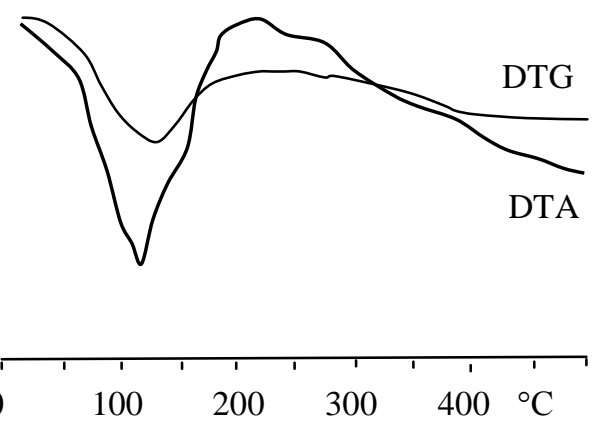

Рисунок 2 - Термограма природного клиноптилоліту

В області $230 \ldots 400{ }^{\circ} \mathrm{C}$ проявляється наступний ендоефект, зумовлений виділенням води за рахунок гідроксильних груп та кристалогідратної води. Інтенсивність цього ендоефекту $є$ меншою, ніж попереднього, однак його інтегральне значення, як і втрата маси в цій температурній області, є сумірними 3 першим. Вміст фізично сорбованої води у клиноптилоліті, який зберігався за кімнатної темпе- 
ратури, становив близько 55 \% від іiї загального вмісту. За подальшого підвищення температури понад $400{ }^{\circ} \mathrm{C}$ спостерігався ще один ендоефект, який, проте, відбувався практично без втрати маси. Це пояснюється зміною структури клиноптилоліту, яка може супроводжуватись міграцією обмінних катіонів.

На підставі отриманих результатів подальші дослідження з впливу температури на дегідратацію клиноптилоліту проводили в діапазоні температур $100 \ldots 400^{\circ} \mathrm{C}$.

Залежність ступеня дегідратації клиноптилоліту від температури, а також під дією НВЧ-випромінювання наведено на рисунку 3.

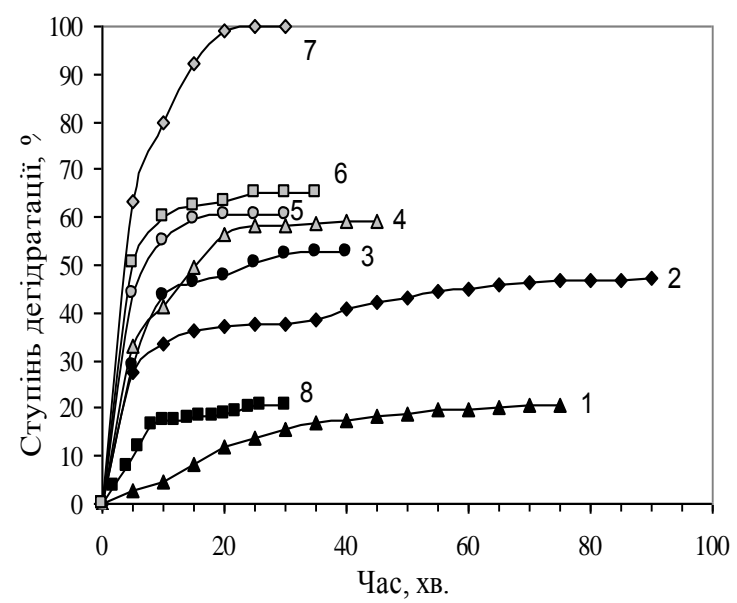

Температура дегідратації, К:

$1-100 ; 2-150 ; 3-200 ; 4-250$ $5-300 ; 6-350 ; 7-400$;

8 - під дією НВЧ-випромінювання

Рисунок 3 - Залежність ступеня дегідратації клиноптилоліту від часу

Швидкість дегідратації на початкових стадіях процесу пропорційна температурі дегідратації (рисунок 4). Збільшення температури в 4 рази (від 100 до $400{ }^{\circ} \mathrm{C}$ ) спричиняє збільшення початкової швидкості дегідратації в 12,4 разу (від $0,3 \cdot 10^{-4}$ до $3,73 \cdot 10^{-4}$ (г $\left.\mathrm{H}_{2} \mathrm{O} / \Gamma \mathrm{K} л \cdot c\right)$.

За температури близько $100{ }^{\circ} \mathrm{C}$ десорбується фізично сорбована вода, тоді як за вищих температур дегідратація відбувається за рахунок цеолітних гідроксильних груп та кристалогідратної води.

Швидкість цього процесу в НВЧ-полі дорівнює $0,575 \cdot 10^{-4}$ (г $\mathrm{H}_{2} \mathrm{O} / \Gamma$ Кл·с), що відповідає температурі дегідратації близько $120^{\circ} \mathrm{C}$. Водночас температура клиноптилоліту, обробленого в полі дії електромагнітних випромінювань, впродовж усього процесу зростає

(C) 3. О. Знак, А. С. Грабаровська, О.І. Зінь, А.В. Дяденчук, 2019 DOI: $10.24025 / 2306-4412.4 .2019 .183209$ всього на $1 . . .2$ градуси. Це зумовлене тим, що кристалічна гратка цеоліту типу клиноптилоліт $\epsilon$ «прозорою» для НВЧ-випромінювань. Після досягнення сталої маси зразка цеоліту його температура не змінюється. Отже, електромагнітне випромінювання 3 частотою близько 2,45 ГГц не поглинається мінералом, а його енергія витрачається лише на видалення саме фізично сорбованої води. Молекули води, як відомо, є диполями. Завдяки цьому НВЧ-випромінювання взаємодіє з молекулами фізично сорбованої води селективно, внаслідок чого вода нагрівається й випаровується, а сам цеоліт при цьому не нагрівається. Через це енергетичні витрати на перебіг дегідратації під дією НВЧ-випромінювань є значно нижчими, ніж у разі термічної.

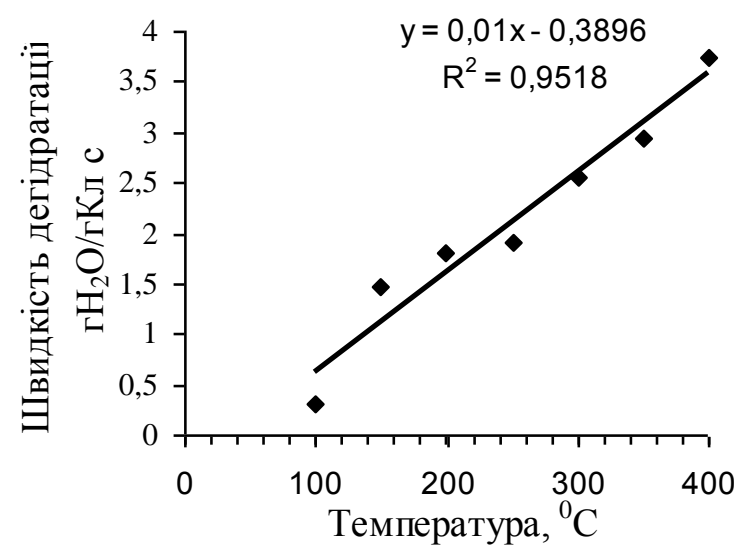

Рисунок 4 - Залежність початкової швидкості дегідратації клиноптилоліту від температури

Залежність тривалості процесу дегідратації (до досягнення сталої маси зразка клиноптилоліту за певних умов) від температури процесу у зазначеному вище діапазоні взагалі також $є$ прямолінійною (рисунок 5), тобто виділення води пропорційне кількості підведеної теплової енергії.

Зразки дегідратованого клиноптилоліту надалі модифікували йонами Аргентуму за температури $20 \pm 2{ }^{\circ} \mathrm{C}$. 3 урахуванням біжучої концентрації йонів Аргентуму в розчині та маси цеоліту розраховували вміст йонів $\mathrm{Ag}^{+} \mathrm{y}$ клиноптилоліті, тобто його сорбційну ємність (рисунок 6). Цей показник вибірково контролювали методом зворотного йонного обміну.

Найменша швидкість процесу, що дорівнювала $2,22 \cdot 10^{-4}$ (ммоль $\left.\mathrm{Ag}^{+}\right) /(\mathrm{c} \cdot \Gamma$ Кл), властива для вихідного цеоліту (швидкість гетерогенного процесу йонного обміну розраховували відносно маси клиноптилоліту, 
оскільки визначення загальної площі поверхні високодисперсних частинок не коректне).

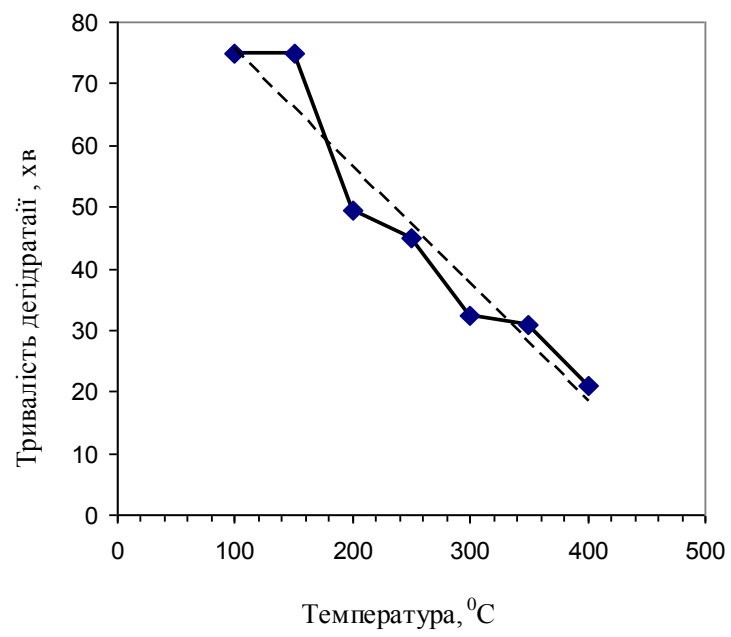

Рисунок 5 - Залежність тривалості дегідратації клиноптилоліту (до досягнення сталої маси) від температури

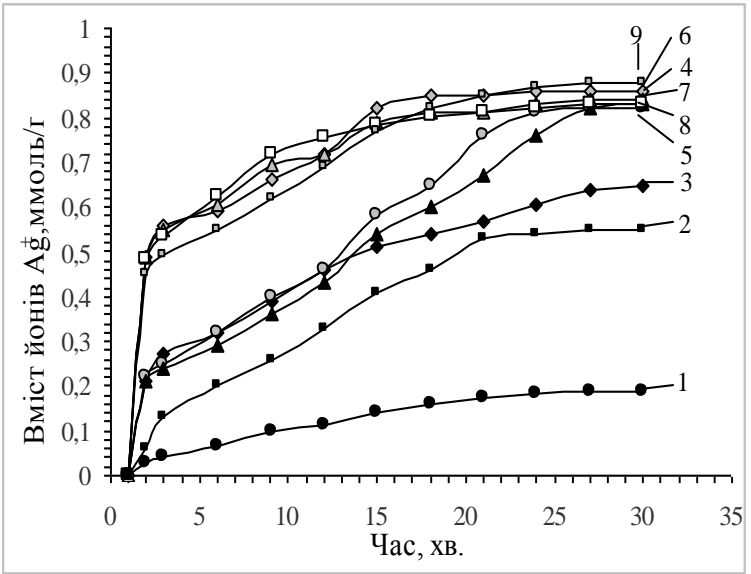

1 - вихідний (недегідратований);

2 - під дією НВЧ-випромінювання;

за температури, ${ }^{\circ} \mathrm{C}: 3-100 ; 4-150 ; 5-200$; $6-250 ; 7-300 ; 8-350 ; 9-400$

Рисунок 6 - Залежність вмісту йонів Аргентуму в клиноптилоліті від часу залежно від умов дегідратації

Швидкість йонного обміну у разі цеоліту, обробленого в НВЧ-полі, збільшувалась у 3,25 разу, порівняно з вихідним клиноптилолітом. При цьому сорбційна ємність щодо йонів $\mathrm{Ag}^{+}$зростала у 2,9 разу.

Цікаво, що початкові швидкості йонного обміну для зразків клиноптилоліту, термоактивованого за температур 100,150 i $200{ }^{\circ} \mathrm{C}$, $\epsilon$ практично однаковими $\mathrm{i}$ дорівнюють $1,39 \cdot 10^{-3}$ (ммоль $\left.\mathrm{Ag}^{+}\right) /(\mathrm{c} \cdot \Gamma \quad$ Кл). Однак після $12 \ldots 13-$ х хв. швидкість процесу за участю це-

(C) 3. О. Знак, А. С. Грабаровська, О.I. Зінь, А.В. Дяденчук, 2019 DOI: $10.24025 / 2306-4412.4 .2019 .183209$ оліту, активованого за $100{ }^{\circ} \mathrm{C}$, зменшилась практично вдвічі, тоді як для двох інших зразків (оброблених за 150 і $200^{\circ} \mathrm{C}$ ) вона залишалася практично сталою ще впродовж наступних $10 \ldots 13$ хв.

Активація цеоліту за 150 i $200{ }^{\circ} \mathrm{C}$ дала змогу досягнути вмісту йонів $\mathrm{Ag}+0,82$ мекв/г, що в 1,26 і 4,3 разу більше, ніж для вихідного (неактивованого) і активованого за $100{ }^{\circ} \mathrm{C}$ відповідно.

Початкова швидкість йонного обміну в клиноптилоліті, обробленому за температур у діапазоні $250 \ldots 400{ }^{\circ} \mathrm{C}, €$ практично сталою (дорівнює $0,85 \pm 0,01$ ммоль/с.г) і більшою в 1,31 разу, порівняно з такою ж для цеолітів, активованих за $100 \ldots 200^{\circ} \mathrm{C}$. Однак після 11...15-ї хв. швидкість процесу істотно зменшується, а після $22 \ldots 25$ хв. практично припиняється - наступає стан рівноваги.

В усіх випадках за тривалості модифікування 30 хв. у розчині досягалось стабільне значення потенціалу Ag-селективного електрода, тобто досягалась рівновага йонного обміну. За цих умов розраховували статичну ємність клиноптилоліту.

Значення статичної ємності клиноптилоліту, активованого за різних температур та у полі НВЧ-випромінювання, щодо йонів $\mathrm{Ag}^{+}$наведено на рисунку 7 .

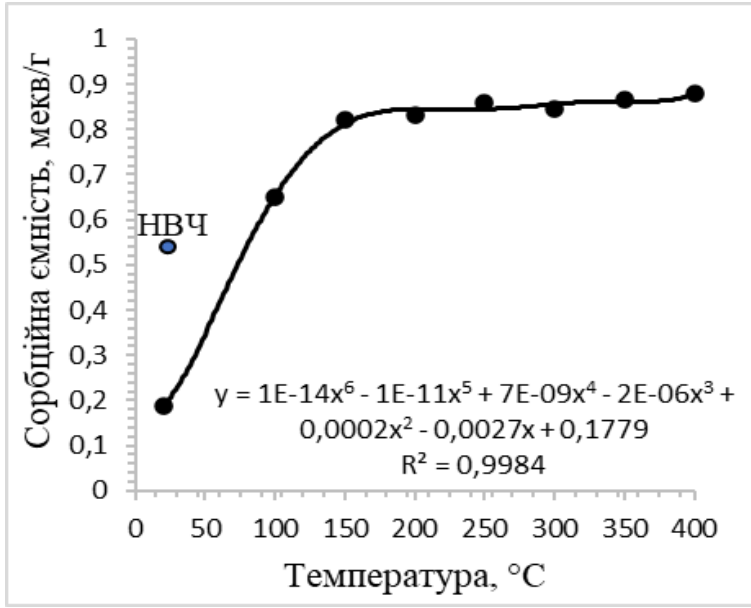

Рисунок 7 - Залежність сорбційної ємності клиноптилоліту від температури активації та під дісю НВЧ-випромінювання

Як видно з рисунка 7, зі збільшенням температури активації від 150 до $400{ }^{\circ} \mathrm{C}$ сорбційна ємність клиноптилоліту зростає незначно: від 0,82 до 0,88 мекв/г, тобто всього в 1,07 разу. При цьому питома витрата енергії на активування зростає суттєво. Очевидно, що 
ефективність використання енергії зі збільшенням температури активації дедалі зменшується й витрачається здебільшого на нагрівання мінералу. Приріст сорбційної ємності у цьому температурному діапазоні дорівнює всього 2,4.10-4 мекв/К.

Активування клиноптилоліту в НВЧполі дає змогу досягнути сорбційної ємності 0,55 мекв/г, яка в 2,9 разу більша, ніж для вихідного цеоліту, і менша в $1,5 \ldots 1,6$ разів, порівняно з цеолітом, обробленим за температур $150 \ldots 400{ }^{\circ} \mathrm{C}$.

Клиноптилоліт Сокирницького родовища характеризується середньою йонообмінною ємністю 1,5 мекв/г. Розрахований ступінь заміщення усіх протийонів, що містяться у цьому цеоліті, на йони Аргентуму дорівнює (\%) для: вихідного клиноптилоліту - 12,6; активованого під дією НВЧ-випромінювання 40,3 ; активованого за температур $\left({ }^{\circ} \mathrm{C}\right): 100-$ 43,$3 ; 150-54,7 ; 200-55,3 ; 250-57,3 ; 300-$ 56,$0 ; 350-56,7 ; 400-58,7$.

Як видно, за температури процесу модифікування $20 \pm 2{ }^{\circ} \mathrm{C}$, незалежно від температури активування цеоліту, статична ємність за йонами Аргентуму не сягає навіть $60 \%$ від теоретично можливої. Те, що максимальний ступінь заміщення обмінних катіонів клиноптилоліту на йони Аргентуму є порівняно невеликим, можна пояснити особливостями перебігу цього процесу. Очевидно, що за умов турбулентного перемішування зовнішньодифузійний опір у системі практично відсутній. Оскільки клиноптилоліт характеризується розвиненою системою каналів (макро-, мезо- і мікро-), наявністю обмінних катіонів $\left(\mathrm{Ca}^{2+}\right.$; $\left.\mathrm{Na}^{+} ; \mathrm{K}^{2+} ; \mathrm{Mg}^{2+}\right)$ гідрокисильних груп і кристалогідратної води, то у внутрішній області частинок цеоліту одночасно відбуваються дифузійні процеси та обмінні рівноважні хімічні реакції.

Попередня термічна активація, як видно 3 отриманих результатів, сприяє збільшенню сорбційної ємності клиноптилоліту завдяки його дегідратації. Причому, за умов проведення експериментів найбільше впливає наявність фізично сорбованої води, яка утримується в цеоліті. Зокрема, це відбувається за рахунок утворення водневих зв'язків молекул води 3 гідроксильними групами. Тому можна вважати, що вилучення гідроксильних груп за температур понад $150{ }^{\circ} \mathrm{C}$ має менший вплив на перебіг йонного обміну.

(C) 3. О. Знак, А. С. Грабаровська, О.І. Зінь, А.В. Дяденчук, 2019 DOI: $10.24025 / 2306-4412.4 .2019 .183209$
Йонний обмін відбувається як обмінна реакція, швидкість якої залежить від температури. Тому надалі модифікування проводили за температур $30,40,50$ i $60{ }^{\circ} \mathrm{C}$ з використанням вихідного (термічно неактивованого) клиноптилоліту.

Зміну сорбційної ємності неактивованого цеоліту в часі наведено на рисунку 8.

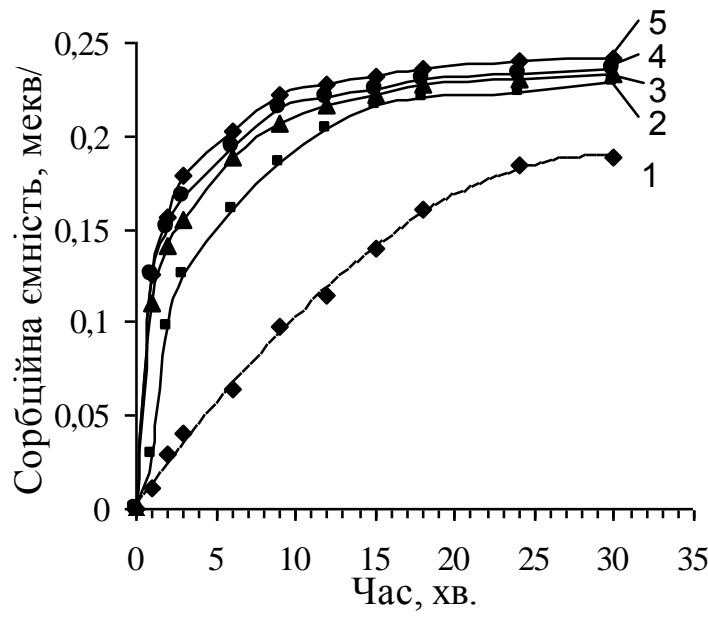

$1-20 ; 2-30 ; 3-40 ; 4-50 ; 5-60$

Рисунок 8 - Залежність сорбційної смності вихідного клиноптилоліту від часу

залежно від температури $\left({ }^{\circ} \mathrm{C}\right)$ модифікування

Підвищення температури від 20 до $30{ }^{\circ} \mathrm{C}$ спричиняє незначне збільшення рівноважної сорбційної ємності за йонами Аргентуму - від 0,189 до 0,229 мекв/г, тобто всього в 1,2 разу. Подальше підвищення температури має ще менший вплив на величину сорбційної ємності. Так, зі збільшенням температури від 30 до $60{ }^{\circ} \mathrm{C}$ сорбційна ємність збільшується від 0,229 до 0,249 - в 1,1 разу.

Початкова швидкість заміщення обмінних йонів на йони $\mathrm{Ag}^{+}$за температур 20;30; $40 ; 50$ і $60^{\circ} \mathrm{C}$ дорівнюе $2,22 \cdot 10^{-4} ; 8,13 \cdot 10^{-4}$; $2,35 \cdot 10^{-3} ; 2,50 \cdot 10^{-3}$ i $2,61 \cdot 10^{-3}$ ммоль/с.г відповідно. Зі збільшенням температури від 20 до $30{ }^{\circ} \mathrm{C}$ температурний коефіцієнт швидкості дорівнює 3,6. Тобто у початковий момент процес відбувається у кінетичній області. Однак надалі, як свідчать отримані результати, модифікування природного клиноптилоліту відбувається у внутрішньодифузійній області. Це можна пояснити переміщенням фронту реакції обміну у внутрішні області частинки та гальмуванням дифузії наявністю обмінних йонів, передусім Кальцію та Магнію. 
Зі збільшенням температури від 30 до $40{ }^{\circ} \mathrm{C}$ і більше значення температурного коефіцієнта швидкості дедалі зменшується і для температур 50 i $60{ }^{\circ} \mathrm{C}$ воно дорівнює лише 1,04, що підтверджує висновок про зміщення області перебігу процесу у внутрішньодифузійну область.

На підставі наведених вище даних розраховано, що у разі здійснення процесу за температури $50 \ldots 60^{\circ} \mathrm{C}$ з використанням термічно активованого (за температури $200 \ldots 400^{\circ} \mathrm{C}$ ) клиноптилоліту можна досягнути сорбційної ємності близько $1,25 \ldots 1,30$ мекв/Г (відповідно ступінь йонного обміну $-83 . .87 \%$ ). Однак ці висновки потребують подальшого експериментального підтвердження.

\section{Висновки:}

1. Найбільша сорбційна ємність клиноптилоліту щодо йонів Аргентуму досягається у разі його термічної активації за температур $200 \ldots 400{ }^{\circ} \mathrm{C}$.

2. Активація клиноптилоліту в полі НВЧ-випромінювання потужністю $400 \pm 25$ Вт дає змогу досягнути сорбційної ємності 0,55 мекв/г, що відповідає температурі активації $120{ }^{\circ} \mathrm{C}$, за одночасно істотного зменшення витрат енергії на дегідратацію.

3. Приріст сорбційної ємності у разі збільшення температури модифікування від 20 до $60{ }^{\circ} \mathrm{C}$ за турбулентного перемішування дорівнює близько $20 \%$, що свідчить про перебіг процесу у внутрішньодифузійній області.

Подальші дослідження будуть спрямовані на вивчення впливу температури модифікування термічно та хімічно активованого клиноптилоліту на його ємність щодо $\mathrm{Ag}^{+}$.

\section{Список літератури}

[1] A. Mažeikiene, M. Valentukevičiene, M. Rimeika et al., "Removal of nitrates and ammonium ions from water using natural sorbent zeolite (clinoptilolite)", Journal of Environmental Engineering and Landscape Management, vol. 16, pp. 38-34, 2008.

[2] N. Taneva, "Removal of ammonium and phosphates from aqueous solutions by activated and modified Bulgarian clinoptilolite", Journal of Chemical Engineering and Materials Science, vol. 3, no.5, pp. 79-85, 2012.

[3] Z. Ying, "Effect of dissolved organic matter on ammonium sorption kinetics and equilibrium to Chinese clinoptilolite", Environmental technology, vol. 33 , no. 21, pp. 23952403, 2012.

[4] I. Pandová, A. Panda, J. Valí cek et al., "Use of sorption of copper cations by clinoptilolite for wastewater treatment ternational", Int. J. Environ. Res. Public Health, (15), pp. 1364-1371, 2018.

[5] J. Peric, M. Trgo, and N. Vukojevic Medvidovi, "Removal of zinc, copper and lead by natural zeolite. A comparison of adsorption isotherms", Water Res., no. 38, pp. 1893-1899, 2004.

[6] A. Zendelska, M. Golemeova, K. Blazev, and A. Krstev, "Adsorption of copper ions from aqueos solutions on natural zeolite", Environ. Prot. Eng., no. 41, pp. 17-36, 2015.

[7] U. Wingenfelder, C. Hansen., G. Furrer, and R. Schulin, "Removal of heavy metals from mine waters by natural zeolites", Environ. Sci. Technol., vol. 39, no. 12, pp. 46064613, 2005.

[8] Y. Sun, Q. Fang, J. Dong et al., "Removal of fluoride from drinking water by natural stilbite zeolite modified with Fe(III)", Desalination, vol. 277, no. 1-3, pp. 121-127.

[9] М. Д. Гомеля, та М. М. Твердохліб, "Дослідження ефективності очищення води від сполук заліза за допомогою модифікованих фільтрувальних завантажень", Восточно-Европейский журнал передовых технологий, № 2/10 (80), с. 47-52, 2016.

[10] 3. О.Знак, та Г. Ф. Винявська, "Кондиціювання природної води щодо вмісту іонів Флюору клиноптилолітом, активованим термічним та електромагнітним методами", Вісник НУ “Львівська політехніка". Хімія, технологія речовин та їх застосування, № 761, с. 6-11, 2013.

[11] K. Shameli, M. B. Ahmad, W. Yunus et al., "Fabrication of silver nanoparticles doped in the zeolite framework and antibacterial activity", International Journal of Nanomedicine, no. 6, pp. 331-341, 2011.

[12] L. Leslie Petrik, R. Missengue, O. Fatoba et al. "Silver/zeolite nano composite-based clay filters for water disinfection", Report to the Water Research Commission. WRC Report no. KV 297/12, 2012, August. 
[13] M. Onal, Y. Sarikaya, and T. Alemdaroglu, "The effect of acid activation on some physico-chemical properties of bentonite", Turkish Journal of Chemistry, no. 26, pp. 409-416, 2002.

[14] А. С. Грабаровська, 3. О. Знак, та Р. Р. Оленич, "Дослідження активування природного клиноптилоліту надвисокочастотними електромагнітними випромінюваннями", Chemistry, Technology and Application of Substances, т. 1, № 2, c. 2126, 2018.

\section{References}

[1] A. Mažeikiene,

M. Valentukevičiene, M. Rimeika et al., "Removal of nitrates and ammonium ions from water using natural sorbent zeolite (clinoptilolite)", Journal of Environmental Engineering and Landscape Management, vol. 16, pp. 38-34, 2008.

[2] N. Taneva, "Removal of ammonium and phosphates from aqueous solutions by activated and modified Bulgarian clinoptilolite", Journal of Chemical Engineering and Materials Science, vol. 3, no.5, pp. 79-85, 2012.

[3] Z. Ying, "Effect of dissolved organic matter on ammonium sorption kinetics and equilibrium to Chinese clinoptilolite", Environmental technology, vol. 33, no. 21, pp. 23952403, 2012.

[4] I. Pandová, A. Panda, J. Valí cek et al., "Use of sorption of copper cations by clinoptilolite for wastewater treatment ternational", Int. J. Environ. Res. Public Health, (15), pp. 1364-1371, 2018.

[5] J. Peric, M. Trgo, and N. Vukojevic Medvidovi, "Removal of zinc, copper and lead by natural zeolite. A comparison of adsorption isotherms", Water Res., no. 38, pp. 1893-1899, 2004.

[6] A. Zendelska, M. Golemeova, K. Blazev, and A. Krstev, "Adsorption of copper ions from aqueos solutions on natural zeolite", Environ. Prot. Eng., no. 41, pp. 17-36, 2015.
[7] U. Wingenfelder, C. Hansen., G. Furrer, and R. Schulin, "Removal of heavy metals from mine waters by natural zeolites", Environ. Sci. Technol., vol. 39, no. 12, pp. 46064613, 2005.

[8] Y. Sun, Q. Fang, J. Dong et al., "Removal of fluoride from drinking water by natural stilbite zeolite modified with Fe(III)", Desalination, vol. 277, no. 1-3, pp. 121-127.

[9] M. D. Homelia, and M. M. Tverdokhlib, "Investigation of the efficiency of purification of water from iron compounds by modified filtering loads", Vostochno-Evropeiskyi jurnal peredovych tehnologii, no. 2/10 (80), pp. 47-52, 2016 [in Ukrainian].

[10] Z. O. Znak, and H. F. Vuniavska, "Conditioning of natural water from fluorine ions by clinoptilolite, activated by thermal and electromagnetic methods", Visnyk $N U$ "L`vivs`ka politekhnika". Khimiya, tekhnolohiya rechovyn ta yih zastosuvanniya, no. 761, pp. 6-11, 2013 [in Ukrainian].

[11] K. Shameli, M. B. Ahmad, W. Yunus et al., "Fabrication of silver nanoparticles doped in the zeolite framework and antibacterial activity", International Journal of Nanomedicine, no. 6, pp. 331-341, 2011.

[12] L. Leslie Petrik, R. Missengue, O. Fatoba et al. "Silver/zeolite nano composite-based clay filters for water disinfection", Report to the Water Research Commission. WRC Report no. KV 297/12, 2012, August.

[13] M. Onal, Y. Sarikaya, and T. Alemdaroglu, "The effect of acid activation on some physico-chemical properties of bentonite", Turkish Journal of Chemistry, no. 26, pp. 409-416, 2002.

[14] A. S. Hrabarovska, Z. O. Znak, and R. R. Olenych, "Investigation of the activation of natural clinoptilolite by ultra-high frequency electromagnetic radiation", Khimiya, tekhnolohiya rechovyn ta yih zastosuvanniya, vol. 1, no. 2, pp. 21-26, 2018 [in Ukrainian]. 
Z. O. Znak, D. Sc., professor, e-mail: znak_zo@ukr.net

A. C. Hrabarovska, graduate student, e-mail:1584466@ukr.net

O. I. Zin, junior researcher, e-mail: zin.olha@gmail.com

A. V. Dyadenchuk, student

Lviv Polytechnic National University

S. Bandery str., 12, Lviv, 79013, Ukraine

\section{MODIFICATION OF THERMALLY ACTIVATED NATURAL CLINOPTILOLITHE WITH SILVER IONS}

The analysis of the areas of application of natural zeolite - clinoptilolite is carried out. In particular, it is used as a sorbent with cation-exchange properties in the purification of natural and waste waters from non-ferrous and heavy metals, radionuclides and other harmful components of water. The prospects of modifying clinoptilolite with silver ions are shown. These ions give it antibacterial properties, which significantly expands the scope of its application.

The scheme, as well as a description of laboratory unit and the methodology for carrying out studies related to dehydration as thermal activation and modification of natural clinoptilolite with silver ions, are presented. The results of zeolite dehydration in the temperature range of $100 \ldots$ $400{ }^{\circ} \mathrm{C}$, as well as due to the action of electromagnetic radiation of the microwave range, are presented and analyzed.

The speed of the process and the degree of thermal and electromagnetic dehydration of clinoptilolite are determined. It is shown that, under the influence of electromagnetic oscillations, the degree of dehydration corresponds to thermal activation at a temperature of $120^{\circ} \mathrm{C}$, however, the temperature of the mineral rises at this by no more than 2 degrees. It is found that thermal activation contributes to an increase in the sorption capacity of clinoptilolite relative to silver ions.

An increase in the activation temperature leads to an increase in the rate of ion exchange, however, in the range of dehydration temperatures of $150 \ldots 400{ }^{\circ} \mathrm{C}$, the equilibrium capacity of zeolite with respect to silver ions is almost the same. An increase in the temperature of modification has little effect on the rate and degree of substitution of the exchange zeolite cations with silver ions. This indicates that the modification process takes place in the intradiffusion region. The features of ion exchange in the case of initial and thermally activated samples of clinoptilolite are analyzed.

Keywords: natural sorbents, water purification, clinoptilolite, modification, silver ions, sorption capacity.

Стаття надійшла 11.11.2019

Прийнято 02.12.2019 